\title{
MUTANTS AND WEATHER PARAMETERS AFFECTING THE POPULATION DYNAMICS OF THREE MAJOR INSECT PESTS OF MUNGBEAN
}

\author{
M.M.H. Khan ${ }^{1 *}$, M.M. Islam ${ }^{1}$, M. Asaduzzaman and M.N. Uddin ${ }^{2}$ \\ ${ }^{1}$ Department of Entomology, Patuakhali Science and Technology University \\ Dumki, Patuakhali-8602, Bangladesh. \\ ${ }^{2}$ Department of Agricultural Extension, Barisal, Bangladesh.
}

\begin{abstract}
The study was conducted to know the abundance of aphid, flea beetle and pod borer on the mutants viz., MBM-07-Y-1, MBM-07-Y-2, MBM656-51-2, MBM-527-114, MBM-07-(S)-2, MBM-347-13, MBM-390-94-Y, MBM-427-87-3, MBM-80 (Local) and a variety BARI moog- 6 and the role of weather parameters on the population dynamics of insects at the Agricultural Farm of Patuakhali Science and Technology University from April to June, 2015. Results revealed that the tested mutants did not show resistance against aphid, flea beetle and pod borer. Mutant MBM347-13 had the lowest number of flea beetle while mutant MBM-427-873 , MBM-80(LCAL) and MBM-527-114 had the highest number of flea beetle indicating higher susceptibility to flea beetle. Mutant MBM-390-94$Y$ had the lowest abundance of aphid while BARI moog- 6 had highest aphid abundance. Mutant MBM-347-13 had lowest number of pod borer and MBM-427-87-3 had highest abundance of pod borer followed by MBM-07(S)-2 and BARI moog-6. Flea beetle abundance gradually increased with decreasing average temperature while aphid and pod borer abundance gradually increased with increasing average temperature. In case of humidity, flea beetle abundance increased very slightly with increasing average humidity but aphid abundance increased very slightly with increasing average humidity. Pod borer abundance was low with high average humidity and then increased slightly due to decrease of humidity and finally declined with increasing humidity.
\end{abstract}

Keywords: Aphid, flea beetle, pod borer, Vigna radiata, temperature, relative humidity

\footnotetext{
* Corresponding author email: mohasin1965@pstu.ac.bd
} 
M.M.H. Khan et al.

\section{INTRODUCTION}

Mungbean (Vigna radiata L.) is an excellent and easily digestible dietary source of vegetable protein. This pulse protein is rich in lysine that is deficient in rice. When it is eaten in combination with wheat, rice and other cereals, it provides a balanced diet for millions of people. According to FAO (1999) recommendation, a minimum intake of pulse by human should be $80 \mathrm{~g}$ per day, whereas it is $14.19 \mathrm{~g}$ in Bangladesh (BBS, 2005). This is because of the fact that national production of the pulses is not adequate to meet our national demand. Mungbean seed contains $52 \%$ carbohydrate, $26 \%$ protein, $10 \%$ moisture, $4 \%$ minerals and 3\% vitamins (Kaul, 1982). Hence, mungbean is the best of all pulses from nutritional point of view (Khan et al., 1982). Being leguminous, this crop maintains soil fertility by fixing the atmospheric nitrogen (Malik, 1994). Mungbean is originated in South East Asia (India, Burma, and Thailand region) and widely grown in India, Pakistan, Bangladesh, Burma, Thailand, Philippines, China, Indonesia and in parts of East and Central Africa, West Indies, USA and Australia (Gowda and Kaul, 1982). In Bangladesh mungbean is grown three times in a year covering 39302 ha with total yield of 31610 metric tons (BBS, 2014). It is tropical and sub-tropical crop resistant to high temperature and in many countries grown as a summer crop and can be cultivated in a wide range of soil. It is sensitive to cloudy weather and cannot tolerate frost (Gowda and Kaul, 1982). There are many constrain responsible for the low yield of mungbean. The poor yield is largely due to varietal aspect, climatic factors, management practices, insect pests and diseases (Rahman et al., 1981).

There are 64 species of insects attack mungbean (Lal, 1985) from seedling to harvest and budding is the most preferred and attractive stage to insects but a total of 16 species have been reported to attack mungbean in Bangladesh. Among them green jassid, bean fly, bean stem fly, whitefly, hairy caterpillar, galerucid beetle and aphids infesting the crops at the seedling stage, vegetative stage and continue to flowering stage while the spotted pod borer damage flower buds, flowers and pods of mungbean (Rahman, 1991). Of these insects pests, white fly, stemfly, hairy caterpillar, and pod borer are the most damaging (Gowda and Kaul, 1982; Rahman et al., 1981). The flea beetles feed on the cotyledons, making the severe innumerable round holes on leaves of young plants and ultimately dried the older damaged leaves of mungbean. Pod borer is one of the serious pests of mungbean in Bangladesh (Rahman et al., 1981), in India (Sehgal and Ujagir, 1988) and other tropical and subtropical countries. The larvae enter into the inflorescence and start feeding the flowers, later they cripple leaves together making nets and nets with leaves, flowers and young pods. They remain inside the nets hiding themselves and eat the young seeds after boring the pods (Rahman et al., 1981). Aphids cause damage to mungbean from flowering onwards and severe infestations most likely reduce plant vigor and yield. Honeydew produced by aphids promotes sooty mould which reduces photosynthesis (Rahman et al., 1981). In view of the above facts, the present research was undertaken to evaluate 9 mutants and a check variety of summer mungbean 
against aphid, flea beetle and pod borer under natural field condition and to know the impact of these mutants and weather parameters on the population dynamics of aphid, flea beetle and pod borer of mungbean.

\section{MATERIALS AND METHODS}

The experiment was carried out at the Agricultural Farm of Patuakhali Science and Technology University during April to June, 2015. The experiment field is located at $22^{0} 37^{\prime} \mathrm{N}$ latitude and $89^{\circ} 10^{\prime} \mathrm{E}$ longitudes. The area is covered Gangetic Tidal Floodplains and falls under Agroecological Zone "AEZ- 13". The area lies at 0.9 to 2.1 metre above mean sea level (Iftekhar and Islam, 2004). The experimental area experiences sub-tropical climate with high temperature and it decreased when the season proceeded towards rabi The climate was characterized by medium rainfall, high humidity and high temperature. Nine mutants viz., MBM-07-Y-1, MBM-07-Y2, MBM-656-51-2, MBM-527-114, MBM-07-(S)-2, MBM-347-13, MBM-390-94-Y, MBM-427-87-3, MBM-80 (Local) and a variety BARImoog-6 were used as study materials. The seeds were collected from Plant Breeding Division, Bangladesh Institute of Nuclear Agriculture, Mymensingh. The experiment was laid out in a Randomized Complete Block Design (RCBD) with three replications. The whole field was divided into 3 unit blocks and each unit block was divided into 10 unit plots. The treatments were randomly distributed in the plots within a block. The total number of plots were 30 and unit plot size was $3.0 \mathrm{~m} \times 2.0 \mathrm{~m}$. The distance between two unit plots was $0.75 \mathrm{~m}$ and between block to block was $1.0 \mathrm{~m}$. The seeds were sown on the $2^{\text {nd }}$ April, 2015 at the rate of $11 \mathrm{~kg} \mathrm{ha}^{-1}$. The seeds were placed in the line continuously at a depth of $6-7 \mathrm{~cm}$ and covered by loose soil by hand. Line to line distance was $30 \mathrm{~cm}$. Urea (@50 kg ha ${ }^{-1}$ ), triple superphosphate (@85 kg ha ${ }^{-1}$ ) and muriate of potash (@35 $\mathrm{kg} \mathrm{ha}^{-1}$ ) were applied as the sources of $\mathrm{N}, \mathrm{P}_{2} \mathrm{O}_{5}$ and $\mathrm{K}_{2} \mathrm{O}$, respectively. Whole amount of urea, TSP and MOP were applied in the field uniformly during the final land preparation. The plants were exposed to natural insect pests infestation and insecticide was not applied during the experimental. Data on different parameters were recorded at 37 and 47 days after sowing (DAS) aphid, at 14, 21 and 30 DAS for for flea beetle and at 50, 57 and 65 DAS for pod borer. Percentage of plant damaged by flea beetle was determined by eye estimation. The total number of infested and healthy plants or leaves was recorded from 15 randomly selected plants of each plot to determine the level of infestation by aphid and flea beetle.

The total number of leaves was counted and percentage of flea beetle infested leaves was calculated. The percentage of pod infestation was calculated by observing 10 randomly selected plants from each plot. During experimental period data on temperature and relative humidity $(\mathrm{RH})$ were collected from the Patuakhali meteorological office. 
M.M.H. Khan et al.

\section{Statistical analysis}

Data were analyzed by using MSTAT software. Means were separated by using Duncan's Multiple Range Test (DMRT).

\section{RESULTS AND DISCUSSION}

\section{Abundance of aphid}

Mean number of aphid plant ${ }^{-1}$ at 37,47 DAS is presented in Table 1. At 37 DAS, significantly the highest number of aphid plant $^{-1}$ was recorded on BARI moog-6 (7.66) followed by that of MBM-427-87-3 (5.33). The lowest number of aphid plant ${ }^{-1}$ was observed on mutant MBM-07-Y-1 (1.00) which statistically similar to that of MBM-390-94-Y (1.00), MBM-07-Y-2 (1.00) and MBM-527-114 (1.00).

At 47 DAS, significantly the highest number of aphid plant ${ }^{-1}$ was also recorded on BARI moog-6 (20.66) and the lowest number of aphid plant ${ }^{-1}$ was recorded on the mutant MBM-390-94-Y (2.00) (Table 1).

Table 1. Mean number of aphid plant $^{-1}$ at 37, 47 days after sowing DAS on nine mutants and a variety of mungbean

\begin{tabular}{l|c|c|c}
\hline \multirow{2}{*}{ Mutants/variety } & \multicolumn{2}{|c|}{ Mean number of aphid plant ${ }^{-1}$} & \multirow{2}{*}{ Mean } \\
\cline { 2 - 3 } & 37 DAS & 47 DAS & $3.34 \mathrm{~cd}$ \\
MBM-07-Y-1 & $1.00 \mathrm{c}$ & $5.67 \mathrm{~cd}$ & $2.00 \mathrm{~d}$ \\
MBM-07-Y-2 & $1.00 \mathrm{c}$ & $3.00 \mathrm{ef}$ & $5.00 \mathrm{c}$ \\
MBM-656-51-2 & $2.66 \mathrm{c}$ & $7.34 \mathrm{c}$ & $3.00 \mathrm{~cd}$ \\
MBM-527-114 & $1.00 \mathrm{c}$ & $5.00 \mathrm{de}$ & $4.00 \mathrm{~cd}$ \\
MBM-07(S)-2 & $1.34 \mathrm{c}$ & $6.67 \mathrm{~cd}$ & $4.34 \mathrm{c}$ \\
MBM-347-13 & $1.34 \mathrm{c}$ & $7.33 \mathrm{c}$ & $1.50 \mathrm{~d}$ \\
MBM-390-94-Y & $1.00 \mathrm{c}$ & $2.00 \mathrm{f}$ & $3.84 \mathrm{~cd}$ \\
MBM-80(LCAL) & $1.67 \mathrm{c}$ & $6.00 \mathrm{~cd}$ & $10.50 \mathrm{~b}$ \\
MBM-427-87-3 & $5.33 \mathrm{~b}$ & $15.67 \mathrm{~b}$ & $14.16 \mathrm{a}$ \\
BARI moog-6 & $7.66 \mathrm{a}$ & $20.66 \mathrm{a}$ & 2.321 \\
\hline LSD (5\%) & 1.830 & 2.141 & 8.16 \\
\hline CV (\%) & 5.16 & 11.36 & \\
\hline
\end{tabular}

Within column means followed by same letter (s) are not significantly different at 5\% level by DMRT.

It was evident that the aphid abundnace plant ${ }^{-1}$ was the highest on BARI moog- 6 which was highly susceptible to aphid followed by that of mutatants MBM-427-87-3. MBM656-51-2, MBM-07(S)-2 and MBM-347-13. The mutant MBM-390-94-Y was the least susceptible to aphid followed by MBM-07-Y-2 and MBM-527-114. None of the tested mutants showed complete resistance against aphid while mutant MBM-390-94-Y was found comparatively tolerant to aphid among the tested mutants and variety. 


\section{Abundance of flea beetle}

Mean number of flea beetle per 15 plants at different days after sowing (DAS) of tested mungbean mutants is presented in Table 2. At 14 DAS, significantly the highest number of flea beetle per 15 plants (41.67) was observed in the mutant MBM-427-87-3. The second highest number was recorded in variety BARI moog-6 (32.34) which was statistically similar to that of MBM-527-114 (31.34). However, significantly the lowest number of flea beetle was observed in the mutant MBM-07Y-2 (14.33).

At 21 DAS, significantly the highest population of flea beetle (45.00) was recorded in the mutant MBM-80(LCAL) followed by MBM-527-114 (41.33) and MBM-427-873 (36.34). The lowest number of flea beetle was found in the mutant MBM-347-13 (19.00) (Table 2).

At 30 DAS, the mutant MBM-80(LCAL) also had the highest population of flea beetle (25.00) followed by MBM-07(S)-2 (23.00). The lowest population of flea beetle was recorded in the mutant MBM-347-13 (13.34) which was statistically similar to MBM-656-51-2 (14.67). The number in mutant MBM-07-Y-2 was statistically identical to that of BARI moog-6. Likewise, the number in mutant MBM-527-114 (21.67) was statistically similar to that of mutant MBM-427-87-3 (20.66) (Table 2).

Table 2. Abundance of flea beetle on nine mutants and a variety of mungbean at different days after sowing (DAS)

\begin{tabular}{l|c|c|c|c}
\hline \multirow{2}{*}{ Mutants/variety } & \multicolumn{2}{|c|}{ Mean number of flea beetle 15 plant $^{-1}$} & \multirow{2}{*}{ Mean } \\
\cline { 2 - 4 } & 14 DAS & 21 DAS & 30 DAS & \\
\hline MBM-07-Y-1 & $21.34 \mathrm{~d}$ & $31.00 \mathrm{e}$ & $17.00 \mathrm{de}$ & $23.11 \mathrm{c}$ \\
MBM-07-Y-2 & $14.33 \mathrm{e}$ & $23.34 \mathrm{~g}$ & $17.67 \mathrm{~d}$ & $18.45 \mathrm{~d}$ \\
MBM-656-51-2 & $20.66 \mathrm{~d}$ & $30.33 \mathrm{e}$ & $14.67 \mathrm{ef}$ & $21.89 \mathrm{c}$ \\
MBM-527-114 & $31.34 \mathrm{~b}$ & $41.33 \mathrm{~b}$ & $21.67 \mathrm{bc}$ & $31.44 \mathrm{a}$ \\
MBM-07(S)-2 & $25.66 \mathrm{c}$ & $34.66 \mathrm{~cd}$ & $23.00 \mathrm{ab}$ & $27.78 \mathrm{~b}$ \\
MBM-347-13 & $21.66 \mathrm{~d}$ & $19.00 \mathrm{~h}$ & $13.34 \mathrm{f}$ & $18.00 \mathrm{~d}$ \\
MBM-390-94-Y & $23.00 \mathrm{~d}$ & $26.66 \mathrm{f}$ & $19.33 \mathrm{~cd}$ & $22.99 \mathrm{c}$ \\
MBM-80 (LCAL) & $25.34 \mathrm{~cd}$ & $45.00 \mathrm{a}$ & $25.00 \mathrm{a}$ & $31.78 \mathrm{a}$ \\
MBM-427-87-3 & $41.67 \mathrm{a}$ & $36.34 \mathrm{c}$ & $20.66 \mathrm{bc}$ & $32.89 \mathrm{a}$ \\
BARI Moog-6 & $32.34 \mathrm{~b}$ & $32.67 \mathrm{de}$ & $17.67 \mathrm{~d}$ & $27.56 \mathrm{~b}$ \\
\hline LSD (5\%) & 2.599 & 2.341 & 2.452 & 2.610 \\
\hline CV (\%) & 12.29 & 9.45 & 10.25 & 13.52 \\
\hline
\end{tabular}

Within column means followed by same letter (s) are not significantly different at $5 \%$ level by DMRT. 
It was evident that the mutants MBM-427-87-3, MBM-80(LCAL) and MBM-527114 had the highest population of flea beetle which indicated that these mutants were highly susceptible to flea beetle. On the other hand, mutant MBM-347-13 had the lowest population of flea beetle which indicated that the mutant was the least susceptible to flea beetle. Among all the tested mutants, none showed complete resistance against flea beetles however, MBM-347-13 showed tolerant against the attack of flea beetle.

\section{Abundance of pod borer}

Mean number of pod borer per 10 plants at 50,57 and 65 days after sowing is presented in Table 3. At 50 DAS, the lowest abundance of pod borer (2.00) was recorded on the mutant MBM-347-13 while no significant differences were observed among that of mutants MBM-07-Y-2 (2.50), MBM-656-51-2 (2.56) and MBM-39094-Y (2.60). The mutant MBM-427-87-3 had the highest number of pod borer per 10 plants (5.89).

At 57 DAS, the mutant MBM-347-13 had also the lowest number of pod borer per 10 plants (2.00) which was statistically similar to that of MBM-390-94-Y (2.33). The mutant MBM-427-87-3 had the highest number of pod borer per 10 plants (7.00) which was statistically similar to that of BARI moog-6 (6.00) (Table 3).

At 65 DAS, the lowest abundance of pod borer per 10 plants was recorded in the mutant MBM-07-Y-1 (2.61). No significant differences were observed among that of mutants MBM-656-51-2 (3.00), MBM-527-114 (4.00), MBM-347-13 (4.00) and MBM-390-94-Y (3.47). The mutant MBM-427-87-3 had the highest number of pod borer per 10 plants (7.67) which was statistically similar to that of BARI moog-6 (7.00) and MBM-80(LCAL) (7.00) (Table 3).

Table 3. Mean number of pod borer per 10 plants on nine mutants and a variety at 50,57 and 65 days after sowing

\begin{tabular}{l|cc|c|c}
\hline \multirow{2}{*}{ Mutants/variety } & \multicolumn{2}{|c|}{ Mean number of Pod borer 10 plants $^{-1}$ at } & \multirow{2}{*}{ Mean } \\
\cline { 2 - 4 } & 50 DAS & 57 DAS & 65 DAS & \\
\hline MBM-07-Y-1 & $3.47 \mathrm{~d}$ & $4.33 \mathrm{~b}$ & $2.61 \mathrm{~d}$ & $3.47 \mathrm{~cd}$ \\
MBM-07-Y-2 & $2.50 \mathrm{de}$ & $3.78 \mathrm{bcd}$ & $4.80 \mathrm{bc}$ & $2.50 \mathrm{de}$ \\
MBM-656-51-2 & $2.56 \mathrm{de}$ & $2.89 \mathrm{de}$ & $3.00 \mathrm{~cd}$ & $2.56 \mathrm{de}$ \\
MBM-527-114 & $3.30 \mathrm{cde}$ & $3.00 \mathrm{cde}$ & $4.00 \mathrm{~cd}$ & $3.30 \mathrm{~cd}$ \\
MBM-07(S)-2 & $5.00 \mathrm{ab}$ & $4.75 \mathrm{~b}$ & $6.50 \mathrm{ab}$ & $5.00 \mathrm{ab}$ \\
MBM-347-13 & $2.00 \mathrm{e}$ & $2.00 \mathrm{e}$ & $4.00 \mathrm{~cd}$ & $2.00 \mathrm{e}$ \\
MBM-390-94-Y & $2.60 \mathrm{de}$ & $2.33 \mathrm{e}$ & $3.47 \mathrm{~cd}$ & $2.60 \mathrm{de}$ \\
MBM-80(LCAL) & $3.00 \mathrm{cde}$ & $4.00 \mathrm{bc}$ & $7.00 \mathrm{a}$ & $3.00 \mathrm{cde}$ \\
MBM-427-87-3 & $5.89 \mathrm{a}$ & $7.00 \mathrm{a}$ & $7.67 \mathrm{a}$ & $5.89 \mathrm{a}$ \\
\hline
\end{tabular}




\begin{tabular}{l|ccc|c}
\hline \multirow{2}{*}{ Mutants/variety } & \multicolumn{2}{|c|}{ Mean number of Pod borer 10 plants $^{-1}$ at } & \multirow{2}{*}{ Mean } \\
\cline { 2 - 4 } & 50 DAS & 57 DAS & 65 DAS & \\
\hline BARI moog-6 & $4.00 \mathrm{bc}$ & $6.00 \mathrm{a}$ & $7.00 \mathrm{a}$ & $4.00 \mathrm{bc}$ \\
\hline LSD (5\%) & 1.319 & 1.087 & 1.902 & 1.023 \\
\hline CV $(\%)$ & 6.17 & 5.87 & 8.27 & 2.46 \\
\hline
\end{tabular}

Within column means followed by same letter (s) are not significantly different at 5\% level by DMRT.

From the mean of all mutants and a check variety the pod borer population was higher in mutant MBM-427-87-3 and was susceptible to pod borer followed by that of MBM-07(S)-2 and BARI moog-6. MBM-07-Y-1, MBM-527-114 and MBM80(LCAL) were found moderately susceptible while MBM-347-13 was the least susceptible to pod borer followed by MBM-390-94-Y, MBM-07-Y-2 and MBM-656$51-2$.

\section{Effect of weather parameters on flea beetle}

Temperature and abundance of flea beetle showed a negative correlation with each other $(\mathrm{r}=0.509)$ (Fig.1). The coefficient of determination $\left(\mathrm{R}^{2}=0.259\right)$ revealed that $25.9 \%$ variation in the population of flea beetle accrued by the variation in mean temperature. Humidity and abundance of flea beetle showed a negative correlation ( $\mathrm{r}$ $=0.100)$ (Fig.2). The coefficient of determination $\left(\mathrm{R}^{2}=0.010\right)$ revealed that very slight i.e., $1.00 \%$ variation in the population of flea beetle accrued by the variation in humidity.

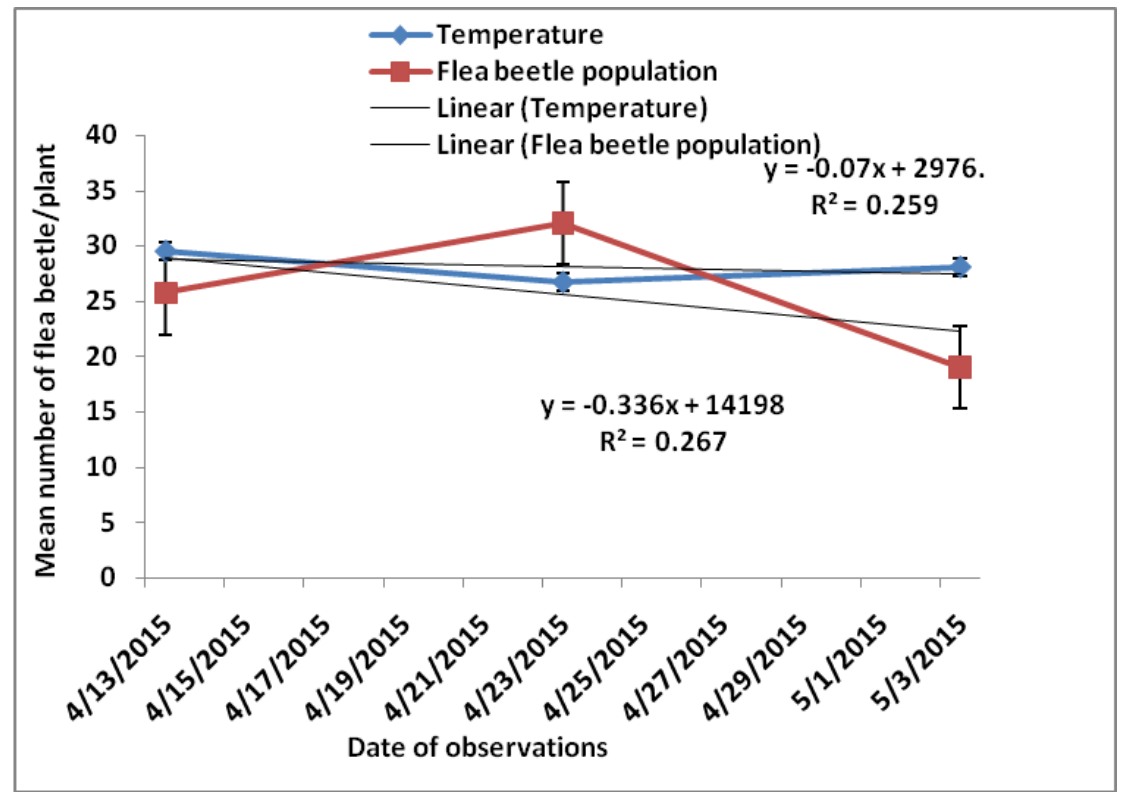

Figure 1. Relationship between mean number of flea beetle with temperature. 


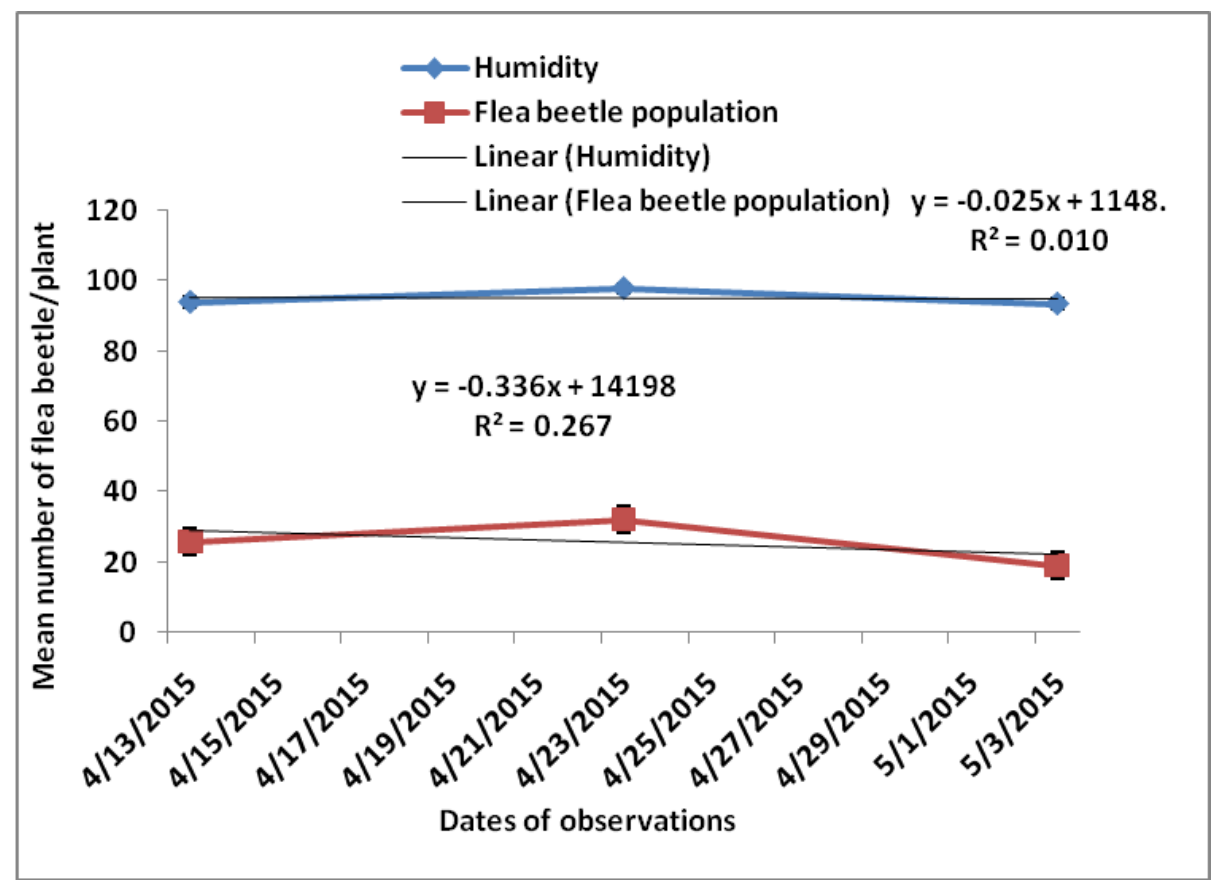

Figure 2. Relationship between mean number of flea beetle with average humidity.

\section{Effect of weather parameters on aphid}

There was a positive relationship $(\mathrm{r}=1.00)$ of the abundance of aphid with temperature (Fig.3). The coefficient of determination $\left(\mathrm{R}^{2}=1\right)$ revealed that $1.00 \%$ variation in the abundance of aphid accrued by the variation in mean temperature. Average humidity and the abundance of aphid showed a positive correlation with each other $(\mathrm{r}=1.00)$ (Fig. 4). The coefficient of determination $\left(\mathrm{R}^{2}=1\right)$ revealed that $1.00 \%$ variation in the population of aphid accrued by the variation in average humidity.

\section{Effect of weather parameters on pod borer}

There was a positive relationship of pod borer with temperature (Fig. 5). Average humidity and abundance of pod borer showed a negative relationship with each other (Fig. 6). 


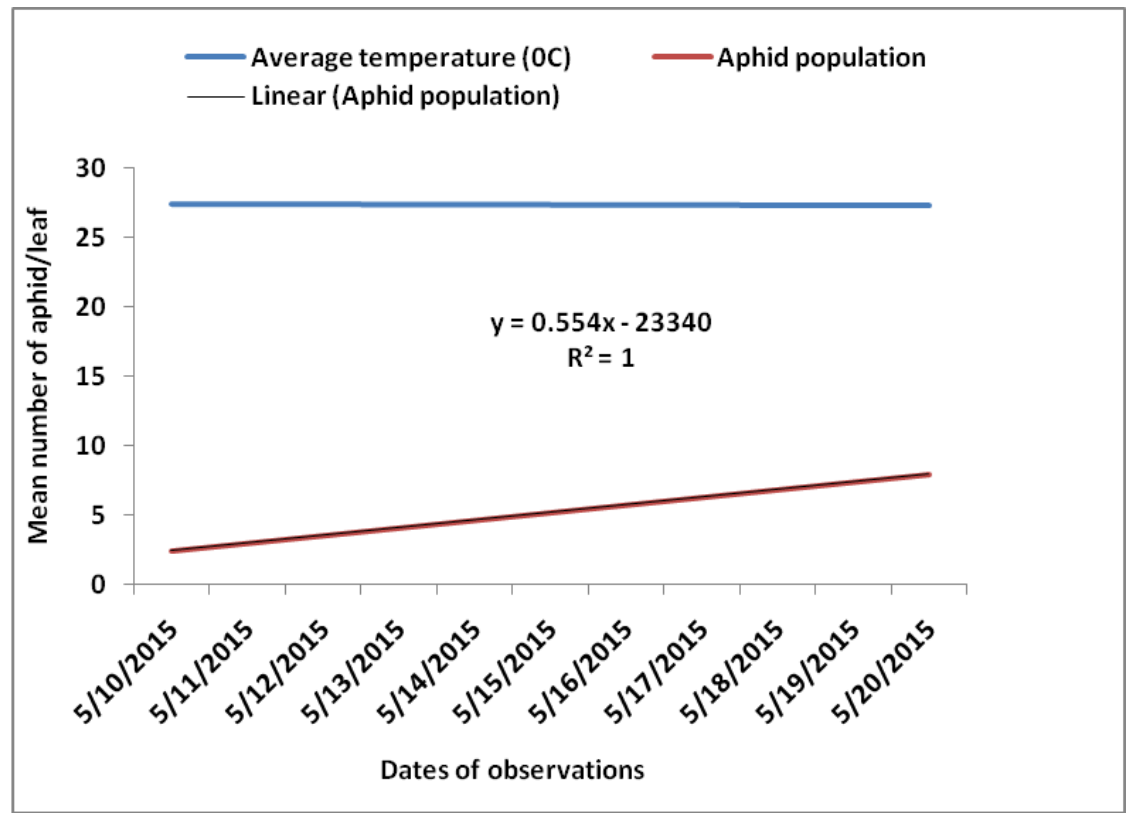

Figure 3. Relationship between mean number of aphid with average temperature.

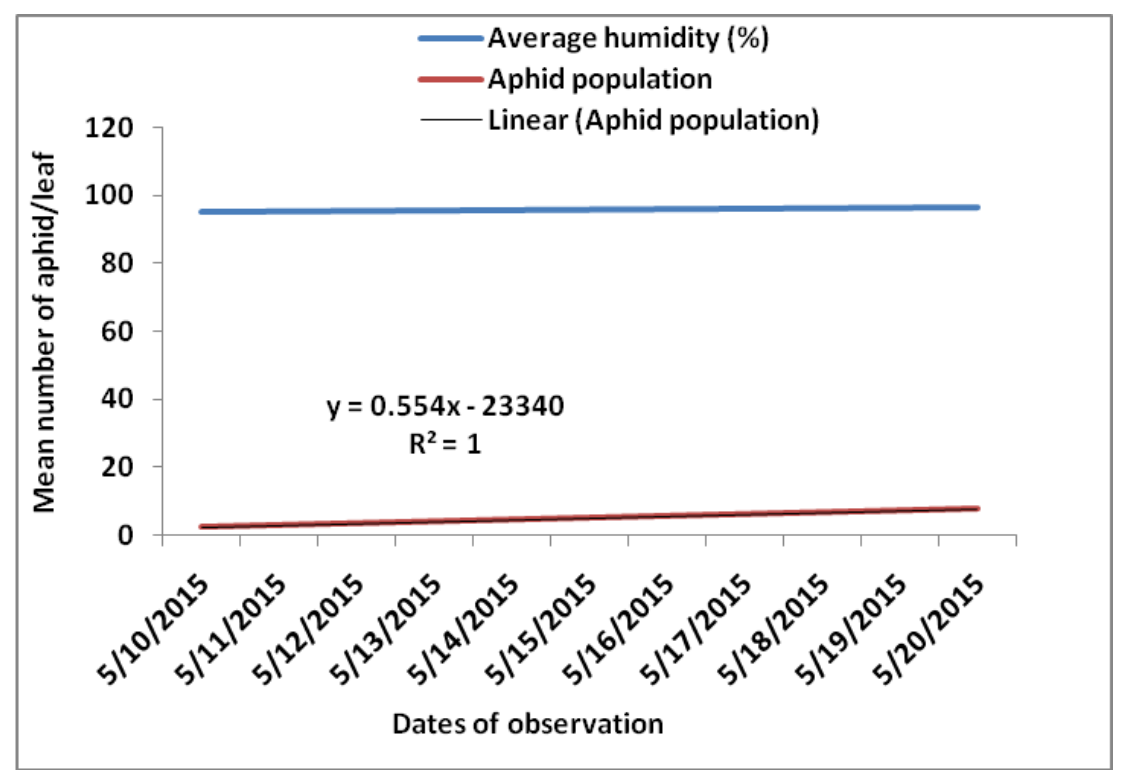

Figure 4. Relationship between mean number of aphid with average humidity. 


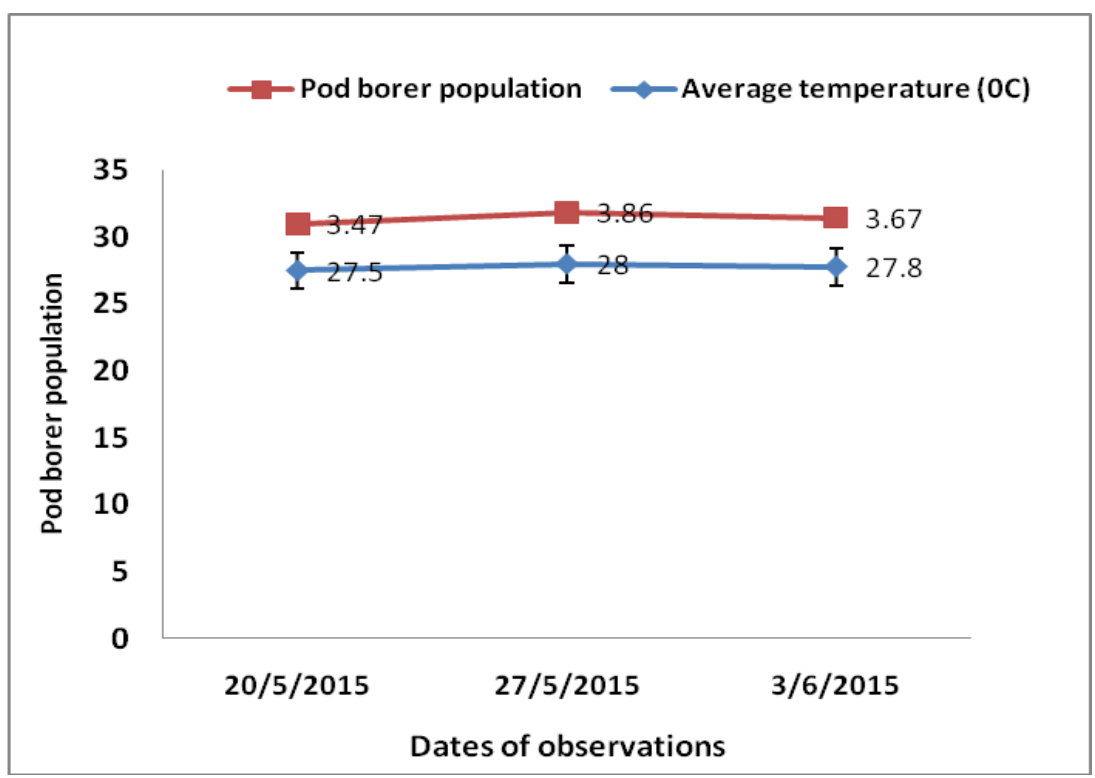

Figure 5. Relationship between mean number of pod borer with average temperature.

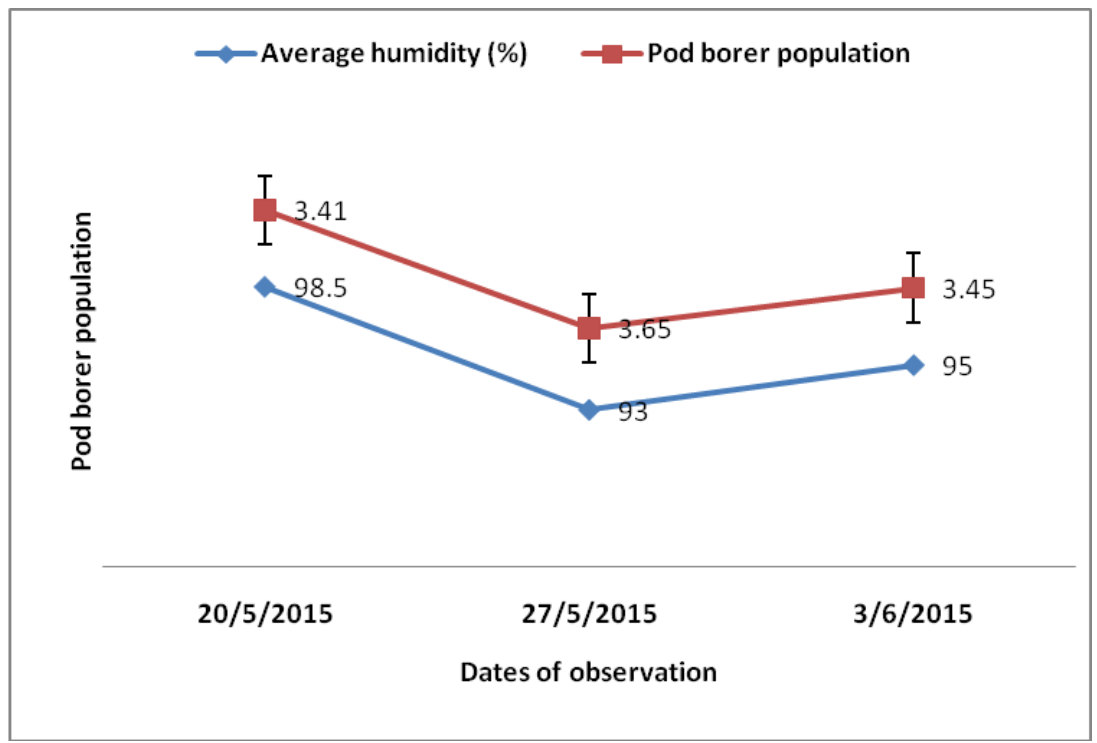

Figure 6. Relationship between mean number of pod borer with average humidity.

The incidence and development of all the insect pests are much dependent upon the prevailing weather conditions; which showed agreement with Aheer et al. (1994). Similar findings are also observed by Hossain et al. (2009) who found that the 
incidence and population fluctuation of various insect pests was very much dependent on the prevailed climatic conditions of the cropping season. Sarkar et al. (2008) observed the severity of major insect pests on mungbean which might be due to variable weather conditions in the two cropping seasons. Mishra and Mukherjee (2015) reported that the three sap feeders of green gram viz., white fly (Bemisia tabaci), thrips (Megaleurothrips distalis) and aphids (Aphis craccivora) were found to attack greengram from 2nd week of January and attainted their peak, i.e., 7, 6 and 26 (nos. plant $^{-1}$ ) at 60, 63 and 68 DAS. Qu and Kogan (1984) reported that the pod borer was wide spread in the tropics and subtropics and also found to be the most damaging pest in mungbean in Asia. Nitharwal and Kumawat (2009) found a significant negative correlation of jassid, whitefly and thrips with maximum temperature and positive correlation of thrips with minimum temperature. Yadav and Singh (2013) found a significant negative correlation of spotted pod borer with minimum relative humidity and positive correlation with sunshine and evaporation.

\section{REFERENCES}

Aheer, G.M., Ahmed K.J., and Ali, A. (1994). Role of weather in fluctuating aphid density in wheat crop. Journal of Agricultural Research, 32(1), 295-301.

BBS. (2005). Preliminary Report on Household Income and Expenditure Survey-2005. Bangladesh Bureau of Statistics.

BBS. (2014). Statistical Yearbook of Bangladesh, Statistics Division, Ministry of Planning, GOB. Bangladesh Bureau of Statistics.

FAO. (1999). FAO Production Yearbook. Basic Data Unit. Statistic Division, FAO. Rome, Italy. Food and Agricultural Organization.

Gowda, C.L.L., and Kaul, A.K. (1982). Pulses in Bangladesh. Bangladesh Agricultural Research Institute, Joydebpur, Dhaka and Food \& Agricultural Organization of the United Nations. pp. 154-167.

Hossain, M.A., Prodhan, M.Z.H., and Sarkar, M.A. (2009). Sowing Dates: A Major Factor on the Incidence of Major Insect Pests and Yield of Mungbean. Journal of Agriculture and Rural Development, 7(1\&2), 127-133.

Iftekhar, M.S., and Islam, M.R. (2004). Managing mangroves in Bangladesh: A strategy analysis, Journal of Coastal Conservation, 10, 139-146.

Kaul, A.K. (1982). Pulses in Bangladesh, BARC. Farmgate, Dhaka. p. 27.

Khan, M.R.I., Shaikh, M.A.Q. and Dutta, P.C. (1982). Nutritional quality characters in pulses. Proc. Natl. Workshop on pulses, August 18-19. 1981, BARI, Gazipur. pp. 199-206.

Lal, S.S. (1985). A review of insect pests of mungbean and their control in India. Tropical Pest Management, 31(2), 105-114.

Malik, B.A. (1994). Grain legumes. p. 277-326. In: Nazir, S., E. Bashir and R. Bantel (Eds.), Crop Production. National Book found., Islamabad, Pakistan.

Mishra, I.O.P., and Mukherjee, S.K. (2015). Field efficacy of newer molecules on sap feeders of green gram Vigna radiata (L.) Wilzeck. Journal of Eco-friendly Agriculture, 10(2), $155-156$. 
Nitharwal, M., and Kumawat, K.C. (2009). Population dynamics of insect pests of green gram, Vigna radiata (Linn.) Wilczek in semi-arid region of Rajasthan. Indian Journal of Applied Entomology, 23(2), 90-92

Qu, Y., and Kogan, J. (1984). A bibliography of three lepidopterous pod borers-Etiella zinckerella, Leguminivora glycinivorella and Matsumaereses phaseoli- associated with mungbean and other legumes. Urbana IL, USA.

Rahman, M.M., Mannan, M.A., and Islam, M.A. (1981). Pest survey of major summer and winter pulses in Bangladesh. In Proc. National Workshop on Pulses (eds.) A.K. Kaul. pp.265-273.

Rahman, M.M. (1991). Control measures for important insect pests of major pulses. In Proc. Second National Workshop on Advances in Pulses Research in Bangladesh, 6-8 June 1989, Joydebpur, Bangladesh. Ptancheru, A. P. 502-324.

Sarkar, M.A., Mannan, M.A., Dutta, N.K., Mahmudunnabi, M., and Salim, M.M.R. (2008). Incidence of major insect pests attacking mungbean in relation to seasonal variation. Bangladesh Journal of Entomology, 18(1), 101-106.

Sehgal, V.K., and Ujagir, R. (1988). Insect and pest management of mungbean in India. Mungbean. In Proc. Second International Symposium. Asian Vegetable Research and Development Center, Shanhua, Taiwan.

Yadav, N.K., and Singh, P.S. (2013). Seasonal abundance of insect pests on mung bean and its correlation with abiotic factors. Journal of Entomological Research, 37 (4), $297-$ 299. 